\title{
Comparative Analysis of Safety and Security Measures in Public and Private Schools at Secondary Level
}

\section{Sabir Ali and Fozia Fatima}

National University of Modern Languages, Islamabad, Pakistan

*Corresponding author: Fozia Fatima, Faculty of Higher Studies National University of Modern Languages, H-9, Islamabad, Pakistan, Tel: 0333-5064632; E-mail: Islamabadfatimafozia@yahoo.com

Rec date: May 07, 2016; Acc date: May 24, 2016; Pub date: May 30, 2016

Copyright: (C2016 Ali S, et al. This is an open-access article distributed under the terms of the Creative Commons Attribution License, which permits unrestricted use, distribution, and reproduction in any medium, provided the original author and source are credited

\begin{abstract}
The basic purpose of this study is "to analyse different safety and security measures in both public and private schools at secondary level in Islamabad." The study was conducted in Islamabad; therefore all the heads of schools constituted as the population of this study. In the sample the number of public schools were 50 and private were also 50. The numbers of male heads of the schools were 56 and female were 44. Checklist for Comparative Analysis of Safety and Security Measures at Secondary level was used to collect the data. It consists of 35 items. Heads of schools responded to the items in three ways either as "Yes" or "No" and further action needed. The findings of this study shows that safety and security measures such as flooring and lighting; number of furniture according to the number of users, stable portable equipment i.e. TV and Computers, good practice of computers among students; fire-fighting equipment, fire evacuation procedures, the evacuation drill; testing of water samples, Remedial actions against exceed limits for bacteria, cold water is used for preparing foods and beverages; emission inspection stickers; Natural disasters, Fires, Chemical or hazardous material spills or releases, Major transportation accidents, Incidents of violence, Bomb threats and acts of terror are most common measure in both public and private school at secondary level. Both male and female heads as well as public and private schools heads had no significant mean differences regarding safety and security measures at secondary level schools in Islamabad, Pakistan.
\end{abstract}

Keywords: Security and safety; School heads; Secondary level schools

\section{Introduction}

A sensible and proportionate approach to ensure a healthy and safe place for all who use them, including the school workforce, visitors and pupils in a school because school premises are a valuable resource for local communities and are increasingly being used for extended services. A highly complex and unique organizations that operate with an urgent imperative: educate and prepare all children and youth to achieve their highest potential and contribute to society, no matter their socioeconomic background or geographic location are considering as educational institutes. All of our schools meet these goals by creating safe, orderly, warm, and inviting school environments. A multitier system of support through collaboration in order to create this type of environment, schools must work towards integrating services (academic, behavioral, social, emotional, and mental health) with the help of this system [1].

Millions of children attend schools that are reasonably safe most of the time because schools develop effective emergency preparedness and crisis prevention, intervention, and response plans that are coordinated with local first responders for the safety of students. In most developing countries, schools fail to protect children from the consequences of natural disasters and accidents. Scientists predict with relative certainty that climate change will increase both the severity and prevalence of natural disasters; schools that cannot withstand catastrophes are unacceptable at a time of increasingly unsafe environments [2].
There are many ways in which schools fail to protect the children entrusted to their care because the problem is not only with natural disasters and accidents. In the face of rapidly changing environment, schools may be remiss by not adequately predicting, preventing and preparing for threats to children's health and safety within a school [3]. The sources of risk and danger are many and complex. A pre-requisite for creating a safe environment in a school is the availability of proper safety or security measures or facilities because school environment plays a pivotal role in the retention and learning outcomes of students [3].

"School Safety shall be infused within the curricula and learning materials with focus on improving school environment and support to needy children in coordination with Departments of Health, Environment and Population at the Federal, Provincial and District levels". (Policy Action No 10, pages 45-46). Therefore, expansion of education provision with corresponding emphasis on the need to reduce risks and security threats from schools and enhance the quality of a safe and secure school. This study helps the educator, practitioners and teachers as well to understand the importance of safety and security measures within and out of the schools for all the concern community of the schools. This study will assist the teacher in making curriculum and management related decisions. This study also help in the development of literature about safety and security measures within a school because it enhance the practice of real learning and effective problem solving techniques and to give a proper shape of a successful safe and secure school. The researchers look forward to working with the administration, congress, and state and local policy makers to help ensure that all schools are safe, supportive, and conducive to learning. 


\section{Statement of the problem}

For launching a country program of safety and security measures at schools, Pakistan needs to take concrete steps and then its institutionalization and sustainability. The basic purpose of this study is "to analyse safety and security measures in both public and private schools at secondary level in Islamabad."

\section{Objectives}

The following are the main objectives of the study:

- To explore safety and security measures at schools.

- To identify the percentage of Movement around the classroom (slips and trips), furniture and fixtures, fire and workplace (ventilation and heating), drinking water and cafeteria, vehicle exhaust entrainment/emission, security, visitors and emergency as safety and security measures at schools.

- To find out means difference between male and female heads of school about safety and security measures at secondary level.

- To analyze the difference in both public and private sectors about safety and security measures at secondary level.

\section{Review of Related Literature}

The single most important desire of all parents is a safe school, where their children can be safe from all types of hazards and risks; probably it is also the desire of everybody else also. At many local and international for a, students themselves have expressed the need for safe schools. The National Assembly resolution on safe schools 2008, GOP policies, the National Disaster Management Authority policy (2008), and Ministry of Education National Education Policy 2009 expressed that people of Pakistan desire safe schools for their children. Safe schools through their various funding and financing options as well as various bi-lateral and multi-lateral donors WB, DFID, UN, among others are promoting disaster risk reduction (DRR). There are various ongoing school safety programs and projects throughout the country by the efforts of NGOs and the Civil Society and Media are actively promoting the need for safe schools through several of its communications tools and avenues. The Yokohoma Strategy, the Hyogo Framework for Action 2005-2015, the UN Decade on Education for Sustainable Development, the Millennium Development Goals, and the 2006-2007 world campaign on disaster reduction entitled "Disaster Risk Reduction Begins at School", and the global knowledge and education platform, etc., are various initiatives at global and regional levels for school safety.

\section{Best Practices for Creating a Safe and Successful Schools}

By effective comprehensive and collaborative efforts requiring the dedication and commitment of all school staff and relevant community members because school safety and positive school climate are not achieved by singular actions like purchasing a designated program or piece of equipment [4]. Some effective approaches to prevent violence and promote learning, sufficient time to implement these approaches and ongoing evaluation requires for safe schools which are followings;

A cohesive approach that facilitates multidisciplinary collaboration, learning supports (e.g. behavioral, mental health, and social services), instruction, and school management within a comprehensive are fully integrated [5].
To promote close school-community collaboration, wellness promotion, and interventions that increase with intensity based on student need through the implementation of multitier systems of support [5].

Improve school-community partnerships into existing school initiatives [4].

Crisis training and plans assimilate with ongoing positive climate and safety efforts with crisis prevention, preparedness, response, and recovery to ensure: (a) are relevant to the school context, (b) reinforce learning, (c) make maximum use of existing staff resources, (d) facilitate effective threat assessment, and (e) are consistently reviewed and practiced [6].

To avoid overly restrictive measures (e.g. armed guards and metal detectors) that can undermine the learning environment and instead combine reasonable physical security measures (e.g. locked doors and monitored public spaces) with efforts to enhance school climate, build trusting relationships, and encourage students and adults to report potential threats by creating balance in physical and psychological safety. Properly trained school resource officers (SROs) are the only school personnel of any type who should be armed if a school determines the need for armed security [4].

Using security personnel or SROs primarily as a substitute for effective discipline policies does not contribute to school safety and can perpetuate the school-to-prison pipeline by employing effective, positive school discipline that: (a) functions in concert with efforts to address school safety and climate; (b) is not simply punitive (e.g. zero tolerance); (c) is clear, consistent, and equitable; and (d) reinforces positive behaviors.

Provide services that are most needed, appropriate, and culturally sensitive to a school's unique student populations and learning communities at the context of each school and district [5].

Educating and preparing all of our children and youth to achieve their highest potential and contribute to society is critical for creating safe, orderly, and welcoming learning environments. It is the responsibility of all the concern people whose work with the administration, congress, and state and local policy makers to shape policies based on these best practices in school safety [1].

\section{The Safety and Security Planning Process}

Make maximum use of existing staff resources such as principals, school mental health professionals, school security personnel, appropriate community stakeholders (such as representatives from local law enforcement and emergency personnel), and other school staff or district liaisons to help sustain efforts over time along training and planning must be relevant to the learning context [5]. Active engagement of the team is often directly linked to appropriate staffing levels that allow time for collaboration and planning. Additionally, crisis and emergency preparedness plans must be consistently reviewed and practiced, which is more easily facilitated by an actively engaged team that links the school to the broader community [5].

School safety and security plan include many things to consider when developing a plan at district level. There are four phases in any safety and security plan because the planning process takes time and is an ongoing emergency management; mitigation and prevention, preparedness, response, and recovery, help to establish a foundation for planning. All phases are interconnected and impact on the outcomes of 
each phase. Additionally, when formulating its Safety and Security plan; the following six (6) basic steps may be of assistance to the school district:

A district-wide planning: A district wide planning teams is assembled and the team should at least include administrators, parents, teachers, and maintenance, transportation, food service, and nursing personnel from within the district. Outside agencies that should be involved include law enforcement, fire, hospital, and emergency management personnel.

Analysis of site and surrounding area: Identify what hazards are likely to affect the area in and around your school. Determine the severity of impact of each identified hazard. Local emergency management personnel can assist with this assessment.

\section{Eliminate hazards}

- Determine if you can eliminate or mitigate any of the hazards you identify in step 2 .

- Develop procedures to respond to hazards.

- Develop written procedures on how to respond to the hazards identified in step 2 that cannot be eliminated

Train students and staff: Students and staff must be trained how to use the plan and what their responsibilities will be in a given response.

Conduct drills and tabletop exercises: Drills and tabletop exercises should be conducted to test the plan. All participants should be debriefed at the conclusion of each drill. The feedback provided by participants is used to identify strengths and weaknesses in the plan. The plan is then modified to strengthen any weaknesses.

\section{School Safety and Security Measures in Pakistan}

A system based approach of analyzing and responding to school safety issue on a life-cycle application require school safety with extracting broad parameters of school safety and disaster risk reduction from the Hyogo Framework for Action, Pakistan not only a signatory of which but also reports annually to the UN in terms of progress towards Hyogo Framework implementation in Pakistan. A holistic perspective and with practice to policy connect-following six key inter-linked elements of school safety that encompass safe schools, therefore are of prime relevance.

\section{Policy and institutional mechanisms for promoting school safety}

The ability to incorporate local knowledge and cultural contexts in the implementation of risk reduction are the main part of school safety on national/local level policy requirements and bottlenecks in enforcing safer school construction, along with institutional mechanisms and systems to support implementation. "Principles of good governance, flexibility to change over time include issues related to enabling laws, regulations, guidelines and institutional practices at national, provincial, local and community level, and compliance to facilitate risk reduction and mitigation are included". At the local vulnerability, models of best practices in lowering of risk threshold of designing and applying policy tools and instruments.

\section{Technical aspects of seismically safer schools}

Physical planning elements of hazard mitigation for critical infrastructure are included sharing, understanding and using of engineering designs/structural solutions for safer school construction, including school sites, especially in earthquake, tsunami and cyclone prone are as part of this element [7]. Models and good practices for safe school construction, prioritization of school retrofitting, costeffective retrofit techniques, as well as issues related to design and construction codes and guidelines, options for designs, and appropriate construction materials for school construction in varying terrain. Insufficient and inefficient use of materials and building technologies are also part of school safety element [7].

\section{Integrating disaster risk reduction information in formal/ informal education}

Child focused initiatives, knowledge exchange, grass-roots collaboration, public community-level interaction, and linking and scaling-up with large-scale campaigns utilizing media and social marketing processes are essential part of the school safety element in strategic interventions for public raising risk awareness and response through various tools in the models and safety practices within school.

\section{Community preparedness for disaster prevention and response}

Process of community based assessments of local hazards, vulnerability and capacity assessment, and planning and implementation of risk reduction at the school-community level is also a part. Issues and practices related to programmatic and operational requirements of designing, designating, and operations of community infrastructure as 'safe haven' within local communities, to provide "continuity-of-service" in post disaster scenarios is integral to this element of school safety. Community preparation and response interventions, facilities and provisions; and development and practice of response-preparedness skills, are also included [4].

\section{Public-private partnerships for safe schools}

The business development process as well as means of risk transfer is key component to this school safety include element Incentives/ involvement of private sector investments and financing in all elements of safe schools as part of shift from post disaster relief and reconstruction (RR) to pre-disaster prevention and preparedness (PP) investment in disaster reduction and its integration within the development planning process is included safeguarding investments; and corporate social responsibility, etc... along with new opportunities and innovative partnership leading to safer schools and safer communities are part of this school safety element [1].

There are a few challenges and a few barriers that inhibit schools from becoming safe for our children where in case of Pakistan, there is much requirement and many opportunities to address school safety as there is a will, and there are various ways to respond to this most pressing need, some of these challenges and barriers pertain to:

- Lack of micro or macro science based assessment of all risk, at all levels

- Lack of awareness and investments in school disaster prevention

- Lack of school risk reduction integration in the development planning process

- Lack of physical and social planning concepts application

- Lack of risk management plan development 
Page 4 of 8

- Lack of research and application on appropriate and affordable material and technology for school infrastructure development for various types of hazards

- Lack of ground-trothing of applied solution, exchange of knowledge

- Lack of development, application and enforcement of appropriate construction policies, codes, rules, and practices

- Lack of skilled local human resources in subsistence economies

- Lack of intervention prioritization guidelines and decision making

- Lack or transparent approach between ethics and expediency (USAID, 2011)

New initiatives being undertaken by the public, private, and civil society institutions in promoting safe schools in the country due to the above challenges and barriers, however, are not insurmountable, as evident by many ongoing and emphasis being on risk reduction to children at school, rather than just preparing to respond to another probable hazard risk related catastrophe should that occur where the children will suffer yet again. This study is trying to analyze different safety and security measures in both public and private schools at secondary level in Islamabad.

\section{Methodology}

\section{Population of the study}

This study was conducted in Islamabad; therefore all the heads of schools constituted as the population of this study. Private and public schools were selected as part of the study from Islamabad.

\section{Sample of the study}

Sample was taken randomly from target population of heads from public and private schools of Islamabad. In the sample, total 100 private and public schools were included. In the sample the number of public schools were 50 and private were also 50 . The number of male heads of schools 56 and female were 44 .

\section{Research instrument}

Checklist for comparative analysis of safety and security measures in public and private schools at secondary level was used to collect the data. It consists of 35 items. All items were sub divided into sub scales. There were six sub scales in the questionnaire. The six sub scales were about the different types of safety and security measures at school. The names of sub scale were movement around the classroom (slips and trips), furniture and fixtures, fire and workplace (ventilation and heating), drinking water and cafeteria, vehicle exhaust entrainment/ emission, security, visitors and emergency. Heads of schools responded to the items in three ways either as "Yes" or "No" and further action needed.

\section{Data collection}

Data were collected personally and the researcher himself administered the Checklist. Checklist was distributed among the heads of selected public and private schools.

\section{Data analysis}

Data were analysed through software SPSS. Means, Percentage and independent sample t-test were used to test the objectives of present study. The significant level was 0.05 . The finding was presented in the form of tables.

\section{Results}

The study intended to analyse different safety and security measures in both public and private schools at secondary level in Islamabad (Table 1).

\begin{tabular}{|c|c|c|c|c|}
\hline \multirow[t]{2}{*}{ No } & Safety and Security Measures & Yes & No & FAN \\
\hline & Movement around the classroom (slips and trips) & $\%$ & $\%$ & $\%$ \\
\hline 1 & Is the internal flooring in a good condition? & 75 & 8.3 & 0.0 \\
\hline 2 & Are there any changes in floor level or type of flooring that need to be highlighted? & 25 & 41.7 & 16.7 \\
\hline 3 & Are trailing electrical leads/cables prevented wherever possible? & 58.3 & 25 & 0.0 \\
\hline 4 & Is lighting bright enough to allow safe access and exit? & 75 & 8.3 & 0.0 \\
\hline 5 & Are procedures in place to deal with spillages, e.g. water, blood from cuts? & 50 & 8.3 & 25 \\
\hline 6 & Are access stairs or ramps provided with handrails? & 50 & 8.3 & 25 \\
\hline 7 & Are access steps or ramps properly maintained? & 41.7 & 25 & 16.7 \\
\hline \multicolumn{5}{|c|}{ Furniture and fixtures } \\
\hline 8 & Are permanent fixtures in good condition and securely fastened, e.g. cupboards, display boards, shelving? & 33.3 & 50 & 16.7 \\
\hline 9 & Is furniture in good repair and suitable for the size of the user, whether adult or child? & 75 & 8.3 & 16.7 \\
\hline 10 & Is portable equipment stable, e.g. a TV and computer sets on a suitable trolley? & 75 & 8.3 & 16.7 \\
\hline 11 & Where window restrictors are fitted to upper-floor windows, are they in good working order? & 0.0 & 83.3 & 16.7 \\
\hline
\end{tabular}


Citation: Ali S, Fatima F (2016) Comparative Analysis of Safety and Security Measures in Public and Private Schools at Secondary Level. J Socialomics 5: 169. doi:10.41 72/2167-0358.1000169

Page 5 of 8

\begin{tabular}{|c|c|c|c|c|}
\hline 12 & $\begin{array}{l}\text { Are hot surfaces of radiators etc protected where necessary to prevent the risk of burns to vulnerable young } \\
\text { people? }\end{array}$ & 33.3 & 25 & 25 \\
\hline 13 & Have pupils been advised about good practice when using computers? & 83.3 & 0.0 & 0.0 \\
\hline 14 & Are fixed electrical switches and plug sockets in good repair? & 50 & 33.3 & 0.0 \\
\hline 15 & $\begin{array}{l}\text { Has portable electrical equipment, e.g. laminators, been visually checked and, where necessary, tested at suitable } \\
\text { intervals to ensure that it's safe to use? (There may be a sticker to show it has been tested). }\end{array}$ & 25 & 33.3 & 25 \\
\hline \multicolumn{5}{|c|}{ Fire and Workplace (ventilation and heating) } \\
\hline 16 & Is fire-fighting equipment in place in the classroom? & 83.3 & 0.0 & 0.0 \\
\hline 17 & Are fire evacuation procedures clearly displayed? & 83.3 & 0.0 & 0.0 \\
\hline 18 & Are you aware of the evacuation drill, including arrangements for any vulnerable adults or children? & 83.3 & 0.0 & 0.0 \\
\hline 19 & Does the room have natural ventilation? & 58.3 & 25 & 0.0 \\
\hline 20 & Can a reasonable room temperature be maintained during use of the classroom? & 58.3 & 8.3 & 0.0 \\
\hline 21 & Are measures in place, for example blinds, to protect from glare and heat from the sun? & 50 & 25 & 8.3 \\
\hline \multicolumn{5}{|c|}{ Drinking water and cafeteria } \\
\hline 22 & All drinking fountains in the schools have been checked properly. & 58.3 & 25 & 0.0 \\
\hline 23 & A program of testing of water samples has been implemented. & 83.3 & 0.0 & 0.0 \\
\hline 24 & Remedial actions have been implemented for any fountains that exceed limits for bacteria. & 83.3 & 0.0 & 0.0 \\
\hline 25 & The water supply has an operator. & 25 & 41.7 & 16.7 \\
\hline 26 & All known cross connection have been eliminated or properly protected. & 33.3 & 25 & 25 \\
\hline 27 & Foods and eating items are properly tested. & 41.7 & 25 & 16.7 \\
\hline 28 & Only cold water is used for preparing foods and beverages. & 83.3 & 0.0 & 0.0 \\
\hline \multicolumn{5}{|c|}{ Vehicle exhaust entrainment/emission, security, visitors } \\
\hline 29 & Buses and other vehicles are not allowed to idle for more than 5 minutes. & 41.7 & 41.7 & 0.0 \\
\hline 30 & $\begin{array}{l}\text { School buses and others vehicles owned by the school district have current safety and emission inspection } \\
\text { stickers. }\end{array}$ & 83.3 & 0.0 & 0.0 \\
\hline 31 & $\begin{array}{l}\text { Contracts for buses owned by private firms include language requiring school buses to have current safety and } \\
\text { emission inspection stickers. }\end{array}$ & 83.3 & 0.0 & 0.0 \\
\hline 32 & Proper gatekeepers and guards are present around and within the organization. & 41.7 & 33.3 & 8.3 \\
\hline 33 & Proper security cameras are adjusted around and within the organization & 8.3 & 75 & 0.0 \\
\hline 34 & Registered visitors are only allowed to come in the organization. & 58.3 & 25 & 0.0 \\
\hline \multicolumn{5}{|c|}{ Emergency } \\
\hline \multirow[t]{7}{*}{35} & \multicolumn{4}{|l|}{ Organization is capable to handle and trained their employees and students in following sudden unforeseen crisis; } \\
\hline & Natural disasters (earthquakes, floods) & 83.3 & 0.0 & 0.0 \\
\hline & Extreme weather (storms, heat) & 41.7 & 16.7 & 25 \\
\hline & Fires (building fires, wildfires) & 83.3 & & 0.0 \\
\hline & \multirow[t]{2}{*}{ Chemical or hazardous material spills or releases (liquid mercury) } & 83.3 & 0.0 & 0.0 \\
\hline & & 83.3 & 0.0 & 0.0 \\
\hline & Major transportation accidents (bus, car, motorcycle, bike or skate board crashes) & 83.3 & 0.0 & 0.0 \\
\hline
\end{tabular}


Citation: Ali S, Fatima F (2016) Comparative Analysis of Safety and Security Measures in Public and Private Schools at Secondary Level. J Socialomics 5: 169. doi:10.41 72/2167-0358.1000169

Page 6 of 8

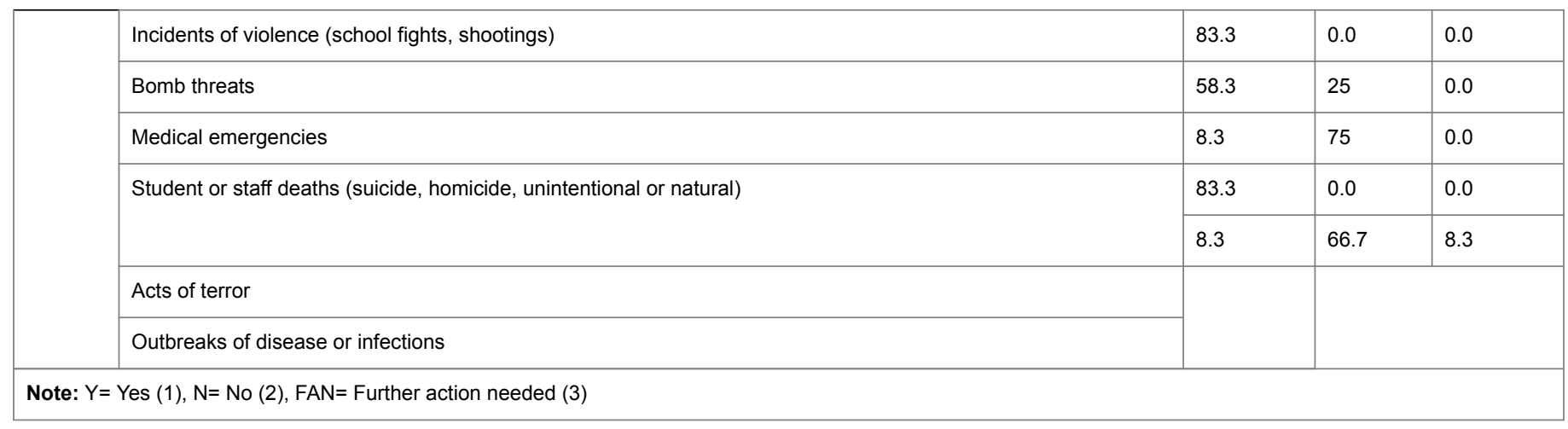

Table 1: Percentage of school heads' responses regarding safety and security measures.

The above table shows different safety and security measures such as Movement around the classroom (slips and trips) in which flooring (75\%) and lighting(75\%); Furniture and fixtures in which number of furniture according to the number of users(75\%), stable portable equipment i.e. TV and Computers (75\%), good practice of computers among students (83.3\%); Fire and Workplace (ventilation and heating) in which fire-fighting equipment $(83.3 \%)$, fire evacuation procedures (83.3\%), the evacuation drill (83.3\%); Drinking water and cafeteria in which testing of water samples (83.3\%), Remedial actions against exceed limits for bacteria (83.3\%), cold water is used for preparing foods and beverages(83.3\%); Vehicle Exhaust Entrainment/ Emission, Security, Visitors in which emission inspection stickers (83.3\%) and Emergency in which measures related to Natural disasters $(83.3 \%)$, Fires (83.3\%), Chemical or hazardous material spills or releases $(83.3 \%)$, Major transportation accidents $(83.3 \%)$, Incidents of violence (83.3\%), Bomb threats $(83.3 \%)$ and acts of terror $(83.3 \%)$ are common measures in both public and private schools at secondary level in Islamabad (Table 2).

\begin{tabular}{|l|l|l|}
\hline S. NO & Safety and Security Measures & Percentage (\%) \\
\hline 1 & Movement around the classroom (slips and trips) & $16 \%$ \\
\hline 2 & Furniture and fixtures & $19 \%$ \\
\hline 3 & Fire and workplace (ventilation and heating) & $12 \%$ \\
\hline 4 & Drinking water and cafeteria & $16 \%$ \\
\hline 5 & Vehicle exhaust entrainment/emission, security, visitors & $13 \%$ \\
\hline 6 & Emergency measures & $23 \%$ \\
\hline
\end{tabular}

Table 2: Percentage of different safety and security measures at schools.

Table 2 shows the percentage of different safety and security measures at school in which movement around the classroom (slips and trips) which was found to be $16 \%$, furniture and fixtures which was found to be $19 \%$, fire and workforce (ventilation and heating) was found to be $12 \%$, drinking water and cafeteria which was found to be $16 \%$, vehicle exhaust entertainment/emission, security, visitors which found $13 \%$ and emergency measures which were found to be $23 \%$.
Its means both public and private schools mostly work at emergency measures (23\%) and furniture and fixtures (19\%) in safety and security measures while in case of fire and workforce $(12 \%)$ and vehicle exhaust entrainment/emission, security, visitors (13\%) need more attention for the sake of safety and security measures at school level.

\begin{tabular}{|l|l|l|l|l|l|l|l|l|}
\hline Variables & Genders & N & Means & Std.Dev. & Std.Error & T & Df & Sig. \\
\hline $\begin{array}{l}\text { Attitude toward Safety and } \\
\text { Security Measures }\end{array}$ & Male & 56 & 62.33 & 2.805 & 1.145 & 0.605 & 98 & 0.440 \\
\cline { 2 - 10 } & Female & 44 & 61.00 & 4.243 & 2.121 & & \\
\hline
\end{tabular}

Table 3: N, Mean, SD and t test of attitude towards safety and security measures of both male and female heads.

Table 3 shows the means of heads' attitude towards Safety and Security measure within their schools at secondary level in Islamabad. The mean of male i.e. 62.33 is greater than the mean of female heads i.e. 61.00 and the difference in means were not found to be significant. So male and female heads had no difference regarding safety and security measures in their respective organizations. 


\begin{tabular}{|l|l|l|l|l|l|l|l|l|}
\hline Variables & Genders & N & Means & Std.Dev. & Std.Error & T & Df & Sig. \\
\hline $\begin{array}{l}\text { Attitude toward Safety and } \\
\text { Security Measures }\end{array}$ & Public & 50 & 62.40 & 3.286 & 1.470 & 0.554 & 28 & 0.908 \\
\cline { 2 - 10 } & Private & 50 & 61.20 & 3.564 & 1.594 & & \\
\hline
\end{tabular}

Table 4: N, Mean, SD and t test for Safety and Security Measures of both Public and Private School.

Table 4 shows the means difference between public and private schools related to Safety and Security measure at secondary level in Islamabad. The mean of public schools i.e. 62.40 is greater than the mean of private schools i.e. 61.20 and the difference in means was not found to be significant. So public and private schools had no difference regarding safety and security measures at secondary level in Islamabad.

\section{Findings}

There are following main findings of this study:

Safety and security measures such as flooring (75\%) and lighting(75\%); number of furniture according to the number of users(75\%), stable portable equipment i.e.; TV and Computers (75\%), good practice of computers among students (83.3\%); fire-fighting equipment $(83.3 \%)$, fire evacuation procedures $(83.3 \%)$, the evacuation drill (83.3\%); testing of water samples (83.3\%); Remedial actions against exceed limits for bacteria $(83.3 \%)$, cold water is used for preparing foods and beverages $(83.3 \%)$; emission inspection stickers (83.3\%); Natural disasters (83.3\%), Fires (83.3\%), Chemical or hazardous material spills or releases $(83.3 \%)$, Major transportation accidents (83.3\%), Incidents of violence (83.3\%), Bomb threats $(83.3 \%)$ and acts of terror $(83.3 \%)$ are common in both public and private schools at secondary level in Islamabad.

Both public and private schools mostly work on emergency (23\%) and furniture and fixtures (19\%) in safety and security measures while in case of fire and workforce (12\%) and vehicle exhaust entrainment/ emission, security, visitors (13\%) need more attention in safety and security measures of a school.

The mean of male i.e. 62.33 is greater than the mean of female heads i.e. 61.00 towards safety and security measures at secondary level in Islamabad.

The mean of public schools i.e. 62.40 is greater than the mean of private schools i.e. 61.20 towards safety and security measures at secondary level in Islamabad.

\section{Discussion}

The basic objective of this study was to explore safety and security measures in schools at secondary level. There were six sub scales about the different types of safety and security measures at school. The names of sub scale are Movement around the classroom (slips and trips), Furniture and fixtures, fire and workplace (ventilation and heating), drinking water and cafeteria, vehicle exhaust entrainment/emission, security, visitors and emergency.

Different safety and security measures were common in both public and private schools because people of Islamabad desire safe schools for their children and for this purpose both sectors work hard related to safety and security measures such as flooring and lighting; number of furniture according to the number of users, stable portable equipment i.e. TV and Computers, good practice of computers among students; fire-fighting equipment, fire evacuation procedures, the evacuation drill; testing of water samples, Remedial actions against exceed limits for bacteria, cold water is used for preparing foods and beverages; emission inspection stickers; natural disasters, fires, chemical or hazardous material spills or releases, major transportation accidents, incidents of violence, bomb threats and acts of terror. It is obligated duty of any educational institutes to ensure peace and security for all lives under its charge, so not only that the all inhabitants may exist, but also that they live a good and safe life because saving all lives is important within a society, all social groups have equal access to means, or resources, to live a life of quality that's why this study shows that due to high terrorism and serious security threats, school mostly work on the emergency issues such as natural disasters, fires, chemical or hazardous material spills or releases, major transportation accidents, incidents of violence, bomb threats and acts of terror [8-10].

The objectives related to mean difference in both male and female heads as well as public and private schools towards safety and security measures at secondary level were have no significant difference because both face same problems so both almost work similarly for the safety and security of their children and educating and preparing all of our children and youth to achieve their highest potential that contribute to society, so it is critical for creating safe, orderly, and welcoming learning environments in both sectors. The results of the study are quite similar to those searched by many other psychologists and researchers like [1-7].

\section{Conclusion}

Safety and security measures such as flooring and lighting; number of furniture according to the number of users, stable portable equipment i.e. TV and Computers, good practice of computers among students; fire-fighting equipment, fire evacuation procedures, the evacuation drill; testing of water samples, Remedial actions against exceed limits for bacteria, cold water is used for preparing foods and beverages; emission inspection stickers; natural disasters, fires, chemical or hazardous material spills or releases, Major transportation accidents, incidents of violence, bomb threats and acts of terror are most common measure in both public and private school at secondary level. Both male and female heads as well as public and private schools towards safety and security measures at secondary level were have no significant difference.

\section{References}

1. Ministry of Education (2002) National Plan of Action on Education for All 2000-2006 Pakistan. Government of Pakistan. Islamabad.

2. UNESCO and USAID (2005) Donor Support to Education. Lesson learned meeting, Islamabad, Pakistan.

3. Fein RA, Vossekuil B, Pollack WS, Modzeleski W, Reddy M, et al. (2002). Threat assessment in schools: A guide to managing threatening situations and to creating safe schools climates. Washington, DC: U.S. Secret Service, and Washington, DC: USA. Department of Education. 
Citation: Ali S, Fatima F (2016) Comparative Analysis of Safety and Security Measures in Public and Private Schools at Secondary Level. J Socialomics 5: 169. doi:10.41 72/2167-0358.1000169

Page 8 of 8

4. Casella R (2002) Where Policy Meets the Pavement: Stages of Public Involvement in the Prevention of School Violence, International Journal of Qualitative Studies in Education 15:3349-372.

5. Haynes NM, Comer JP (1996) Integrating schools, families, and communities through successful school reform: The school development program. School Psychology Review, 25(4):501-506.

6. Daisey JM, Angell WJ (1998) A survey and critical review of the literature on indoor air quality, ventilation and health symptoms in schools, indoor environment program (Report No. LBNL 41517). Prepared for the Office of Environmental Health Hazard Assessment, Lawrence Berkeley National Laboratory, Berkeley, CA.

7. Newmann FM, Wehlage GG (1995) Successful school restructuring: A report to the public and educators by the Center on Organization and
Restructuring of Schools. Madison, WI: Board of Regents of the University of Wisconsin System.

8. European Agency for Safety and Health at Work (2004), Mainstreaming occupational safety and health into education. Good practice in school and vocational education, Office for Official Publications of the European Communities, Luxembourg.

9. European Agency for Safety and Health (2009) at Work, OSH in the school curriculum: requirements and activities in the Member States, Office for Official Publications of the European Communities, Luxembourg.

10. Dwyer, Kevin, Osher, David Safeguarding Our Children: An Action Guide. Implementing Early Warning, Timely Response. Washington, DC, USA. 